\title{
Internationalization and Capital Structure: Evidence from Malaysian Manufacturing Firms
}

\author{
Mohamed Albaity, $\mathrm{PhD}$ (Corresponding author) \\ Department of banking and Finance \\ Faculty of Business and Accountancy \\ University of Malaya \\ Malaysia \\ Email: m_baity@um.edu.my \\ Arison Ho Sel Chuan \\ Faculty of Business and Accountancy \\ University of Malaya \\ Malaysia
}

Received: Nov. 10, 2013 Accepted: December 16, 2013 Published: December 16, 2013

doi:10.5296/ajfa.v5i2.4533 URL: http://dx.doi.org/10.5296/ajfa.v5i2.4533

\begin{abstract}
This paper attempts to examine the determinants of capital structure for internationalized manufacturing firms that are listed on Bursa Malaysia. Firm-related characteristic variables namely internationalization, firm size, profitability, company growth and tangibility over period 2007-2011 are tested their relationship with debt ratio of firms by using panel data Fixed Effects Model. The results showed that firm size and tangibility are significantly positively related with debt ratio while internationalization, profitability and company growth are significantly inversely related with debt ratio. The findings indicate that the static trade-off theory, pecking-order theory and agency theory are pertinent in Malaysia situation.
\end{abstract}

Keywords: Internationalization, Capital Structure, Panel data, Profitability, Malaysia, Manufacturing firms 


\section{Introduction}

In view of the cost and risk involved in debt and equity financing respectively, it is crucial for the managers to choose a suitable capital structure policy for their company, as the financial leverage is one of important factors that will impact the performance of the company. Some empirical studies in Malaysia (Suto, 2003) showed that the capital structure of the firm is negatively related to the performance of companies in different industries in Malaysia. These results imply to us that proper management of the capital structure will generate better returns to the company. Therefore, it will be valuable to managers to know the factors that may impact the capital structure of a firm so that they can control the determinants of the capital structure to maximize firm's profit. However, the previous studies about capital structure still focus on the relationship of firm-related characteristics on capital structure. Many studies have provided empirical evidence that firm-related characteristics such as profitability, tangibility, firm growth, firm size and etc. are important determinants on capital structure (Booth et al, 2001 and Ooi, 1999). Even though studies have found these characteristics to have significant effects on a firm's capital structure, they explain only a small portion of across-firm variations. Other, yet unidentified, factors apparently are at play. One area that remains unexplored is the effect of strategic variables on capital structure (Harris and Raviv, 1991). International diversification plays a key role in the strategic behavior of large firms (Hitt et al 1994) and is important in improving the financial performance of multinational firms (Hull and Lee, 1999). Internationalization has also been shown to be an important determinant of capital structure (Burgman, 1996).

With the globalization and liberalization of economy, many firms choose to invest oversea. The purposes of going abroad are to capture new markets, achieve economy of scales by selling existing products to new customers, spreading the business risk or political risk from one sole country to other safer countries and gaining new technological know-how and management skills if firms from emerging countries invest in developed countries. Therefore, internationalization seems to be one strategic movement for the firms to maximize its value.

Furthermore, many studies regarding capital structure of internationalized firms are mainly focused on developed countries like United Kingdom and United States, while evidence in developing countries like Malaysia is very little (Hitt et al. 1997 and Thomas and Eden, 2004). The recent financial crisis had a very big impact on the firms in Malaysia. Manufacturing sector suffers the most in the financial crisis. During the peak of the financial crisis, Malaysia's export decreased by $27.7 \%$ in January 2009 and it was the biggest reduction in the country history since year 1982 (Malaysia's External Trade statistics, January 2009). Malaysia is an export-based country. Most of the manufactured products are exported oversea. Therefore, manufacturing sector plays an important role in Malaysia's economy. During this financial crisis, many manufacturing companies lost their assets and their share value depreciated. Some companies have undergone capital restructuring. And unlucky ones even ran into bankruptcy.

Rationale of the study

Malaysia has introduced the Third Industrial Plan (IMP3) in 2006. IMP3 starting from 2006 
to 2020 focuses on policies and strategies that help realizes the vision 2020 which is for Malaysia to become a developed country. The Plan leverages upon the strengths and capabilities of manufacturing sector to enhance its competitiveness and resilience in the global platform. With exercise of several Free Trade agreements (FTAs) with ASEAN, China and Japan, reduction of tariff will potentially create better and bigger regional markets that favor and attract the Malaysian manufacturing firms to penetrate into that new markets. Firms may need to extra fund to run their international diversification. However, the potential benefits come along with the challenges from the competitiveness of other FTAs member countries. Firms with weak management in international investment may encounter failure and result in difficulties in debt repayment. Thus, this study with the most recent data of the internationalized firms in manufacturing sector will be able to test and confirm the determinants of these firms' capital structure and the findings might provide the managers in the relevant sectors who wish to employ international diversification strategies with valuable insights in capital structure decisions making process. Therefore this study is focused on examining the determinants influencing the capital structure of public listed manufacturing firms in Malaysia as well as to investigate the influence of internationalization on the leverage of public listed manufacturing firms in Malaysia.

The rest of this paper is organized as follows: next section is literature review which summarizes the determinants of capital structure and internationalization strategy empirical studies. Section three focuses on the methodology used, hypotheses and variables of the study. The results and analysis of this study is discussed in section four. Lastly, part five concludes the study also highlight areas for future study.

\section{Literature Review}

Despite the many researches done, there is a surprising lack of consensus even about many basic empirical facts, such as the determinants of capital structure. Thus, as was the case with leverage measures, there also exist problems of finding, defining and measuring the determinants of capital structure. As Harris and Raviv (1991) showed in their review article, the motives and circumstances that could determine capital structure choices seem nearly uncountable. Generally, the factors that determine capital structure choices observed in the previous study can be categorized into macroeconomic factors such as profitability and firm size, industry specific factors, management control factors and legal factors.

Booth et al (2001) investigated the relationship between debt measures and a set of independent macroeconomic variables, firm specific and institutional variables. Some interesting generalizations emerge from the regression results. The findings indicate that the three proxies used for debt were negatively related to market capitalization and long-term market while GDP and liabilities were positively related to debt. The high growth rate and high inflation have opposite effect on book to market ratio. In addition, the more developed the equity market is the lower the appetite of firms for debt financing. Similarly, the highly developed the debt market the higher the level of debts. Furthermore, higher taxes lead to higher debt ratio in the countries under study.

Ooi (1999) examined the capital structure determinants of 83 property companies in UK 
Growth rate, profitability, and tax rate were statistically insignificant. The result indicates that firms with higher tangible assets employ higher debt. In addition, property companies with high property developments tend to be highly leveraged. Firm size was found to be negatively related to debt. Property firms substitute debt financing with equity financing when stock market is performing well and the opposite is true.

On the other hand, Panno (2003) examined whether capital structure theories from the developed market are applicable to Kenyan firms. Using several variables to study these firms found the following. Debt ratio was negatively related to size and profitability but was positively related to tangible asset. Debt ratio relationship with age depends on the proxy used for age however the result were not statistically significant. The most important variable in explaining debt levels were Profitability, asset structure and size.

Mohd, Perry and Rimbey (1998) examine the effect of the agency costs and ownership concentration on the capital structure of the firm. Using several variables for the period from 1972 to 1989 the findings are as follow. They found negative relationship between institutional and the level of debt. This result accompanied with no significant effect from outside shareholders on the level of debt lead to the conclusion that institutional investor act as a monitoring authority on the firm.

Some of the studies that have been conducted in Malaysia on the subject of capital structure are studies by Mohamad (1995) and Kester and Mansor (1994).

Kester and Mansor (1994) conducted a survey among the Chief executive officers of companies that are listed on Bursa Malaysia in order to find out their view on capital structure policy. Though the majority of executives in Malaysia expressed a preference for similar financing hierarchy as US companies, the results of the survey reveal that they ranked new ordinary shares through right issues ahead of debt. In view of the debt market development in Malaysia, the result may not be as surprising as the debt market in Malaysia is still undeveloped

Internationalization

Chkir and Cosset (2001) using US companies examined the relationship between Multinational companies capital structure. They found that the level of debt acquired by these firms increase as diversification of risk increases.

Similarly, Kwok and Reeb (2000) using "upstream-downstream" hypothesis, which indicate the level of risk exposure by going international, studied the relationship between level of diversification and the level of debt. Using data from 32 countries they found that diversification is negatively related to the level of debt in developed markets. However they found that international diversification is positively related to leverage financing in emerging markets. In concluding they indicate that firms in emerging markets reduce risk by going overseas (upstream), while in developed markets firms increase risk by going international (downstream).

On other hand, Low and Chen (2004) using the same "upstream-downstream" hypothesis on 
232 firms in 30 countries confirm the results by Kwok and Reeb (2000) for the US firms. However, they obtained insignificant results between diversification and leverage for the other markets.

Thomas (2006) using Mexican data studied the relationship between company performance and international diversification. He found that firms experienced negative relationship due to their newness in the international market however, with time the relationship was reversed. These firms managed to exploit the international diversification and earned higher returns. This is relevant to emerging market since most of them are inexperienced in the global market and going to be exposed to new environment. Therefore firms from the emerging markets will be able to increase their performance with time.

Aggarwal and Kyaw (2010) used data from almost 4000 firms for 10 years to study the relationship between international diversification and firm performance measured by dividend payout ratio. The findings indicate that firms exposed to international markets have lower level of debt than domestic firms while the international firm's payout is higher than domestic firms. They indicate that international diversification helps firms reduce their risk and level of debt and increase their payout. Similarly, in confirming Aggarwal and Kyaw (2010) Lin and Hung (2012) compared the capital structure of electronic firms for domestic as well as international firms in Taiwan for 10 years. They found those leverage and dividend payouts are negatively related for international firms while the opposite is true for domestic firms.

Following the study of Singh et al (2003), Thomas (2006), Kwok and Ramirez (2010) and Aggarwal and Kyaw (2010), the proxy used for internationalization here is the foreign sales over total sales ratio in all Malaysian manufacturing firms.

\section{Data and Methodology}

Secondary data will be used to measure the debt ratio and the determinants of capital structure. All the data are collected from database Datastream5 and Bloomberg for the companies listed in Bursa Malaysia under manufacturing sectors. The criteria for the companies are as follow. First, the companies must contain complete financial information for the period 5 years (2007-2011). Second, the companies must have debt financing in their capital structure. Third, the companies must have positive equity because a negative market-to-book equity ratio would not be meaningful to indicate a company's growth opportunity. After eliminating the outliers, the final sample size is 311 companies with a total of 1486 observations.

\section{Hypothesis development}

Capital structure, which is defined as total debt to total assets at book value. In this study, our dependent variable capital structure will be measured by total debt over total assets ratio. We use this measure because it provides information to a firm's policy for both short-term and long term debt.

International diversification leads to a lower volatility of earnings as the MNC has cash flows 
in imperfectly correlated markets. This leads to a reduction in bankruptcy risk and enables the MNC to utilize more leverage in its capital structure (Shapiro, 1992). Thus, the diversification hypothesis predicts a positive relationship between international diversification and financial leverage. Empirical evidence, however, is inconsistent with this assumption. Burgman (1996) and Chen et al. (1997) find a negative relationship between international diversification and leverage. One possible explanation for this is that "the effect of higher agency costs of debt for MNCs, as a result of international capital and labor market imperfections and complexity of international operations exceeds the possible benefits of international diversification and leads to lower debt ratios for MNCs" (Chkir and Cosset, 2001). Kwok and Reeb (2000) propose that the relationship between international diversification and capital structure is dependent on the relative risk of the MNC home country and target country. According to this hypothesis, the capital structure of MNCs can differ between developed countries based and emerging countries based firms. They provide empirical evidence that international diversification is negatively related to leverage for US based firms and positively related to leverage for emerging market-based firms. Based on ISA (International Standard of Accounting) and GAAP (Generally Accepted Accounting Principles), frequently the amount of at least 10 percent foreign sales mentioned as a base for effective internationalization. Hence, all the Malaysian manufacturing firms that have equal or more than 10 percent foreign sales are considered as internationalized firms (dummy $=1$ ), while the Malaysian manufacturing firms with less than 10 percent foreign sales are domestic firms (dummy $=0)$.

\section{$H_{1}$ : Internationalization is negatively related to debt ratio}

Size is considered to be the first important characteristic of firm. The Trade-off theory proposes that the larger a firm is, more needs have to be diversified and this is the reason for it to apply more leverage in its capital structure. This theory also proposes that larger firms can reduce bankruptcy costs by diversifying their businesses. Therefore, it can be said that there is a positive relationship between the size of firm and leverage. Many empirical studies have shown a mixed result. For example, Rajan and Zingales (1995) reported a positive relationship between firm's size and leverage in the US, UK, Japan and Canada, while the result of their study in France show a negative relationship. Thus, we hypothesize that:

\section{$\mathrm{H}_{2}$ : Firm size is positively related to debt ratio.}

Profitability is considered as another important characteristic of firms that can affect capital structure. Based on the Pecking Order theory, companies prefer to be financed by their internal resources. Retained earnings are the first option, then debt is considered as the next option and finally the new equity will be the last resort. As a result, firms with high level of profitability should have the low level of debt. Therefore, according to The Pecking order theory, there is a negative relationship between profitability and leverage. In contrast, the Trade-Off theory depicts a positive relationship between profitability and leverage because the theory states that profitable companies can use more debt to take advantages of the tax-shield. Empirical evidences from previous studies seem to be in line with the pecking order theory. The results of most studies show negative relationship between profitability and 
leverage. For instance, the results of studies by Cassar and Holmes (2003) affirm a negative relationship between profitability and leverage. However, the finding of Petersen and Rajan (1994) is inconsistent with Pecking-Order theory because they reported a positive relationship between profitability and leverage. From the perspective of Pecking-Order theory, larger firms tend to internalize their retained earnings first for further investment rather than borrowing. Thus, we hypothesize that:

\section{$\mathrm{H}_{3}$ : Profitability is negatively related to debt ratio}

Higher growth leads to more investments opportunities which increase the cost of borrowing which leads to internalized funds rather than debt. Moreover, firms experiencing high growth rates prefer not to increase its level of debt because their cash flow might not sustain servicing the debt when needed. For this reason, the relationship between company growth rate and borrowing should be negative. Growth is defined as the market-to-book ratio. Thus, we hypothesize that:

\section{$\mathrm{H}_{4}$ : Company growth is negatively related to debt ratio}

Bevean and Danbolt (2001) showed that tangibility is positively correlated to total and long-term debt ratios respectively but inversely related to short-term debt ratio. From a trade-off perspective, firms with a lot of fixed assets find it easier to issue bonds or get loan from banks because the fixed assets of the company will be able to serve as collateral for the borrowing and reduces the default risk for the lenders. Under the pecking-order theory, the greater the value of the tangible assets, the smaller the asymmetric information, therefore, it is expected that the collateral value might be positively related to the debt ratio. Many previous empirical studies supported this hypothesis. For instance, Rajan and Zingales (1995) supported this hypothesis in industrialized countries. Suto (2003) also supported this hypothesis in Malaysia. Thus, we hypothesize that:

\section{$\mathrm{H}_{5}$ : Tangibility is positively related to debt ratio.}

Testing the earlier hypothesis is done using the following model

DRATIO $_{\mathrm{i}, \mathrm{t}}=\beta_{0}+\beta_{1} \mathrm{INTL}_{\mathrm{i}, \mathrm{t}}+\beta_{2} \mathrm{SIZE}_{\mathrm{i}, \mathrm{t}}+\beta_{3}$ PROFIT $_{\mathrm{i}, \mathrm{t}}+\beta_{4} \mathrm{GROWTH}_{\mathrm{i}, \mathrm{t}}+\beta_{5}$ TANG $_{\mathrm{i}, \mathrm{t}}+\varepsilon_{\mathrm{i}, \mathrm{t}}$

Where DRATIO represents debt ratio, INTL represents internationalization, SIZE represents firm size, PROFIT represents profitability, GROWTH represents company growth and TANG represents tangibility. $\beta_{0}$ is constant, $\beta_{1}, \beta_{2}, \beta_{3}, \beta_{4}$, and $\beta_{5}$ are coefficients of the independent variables, $\mathrm{I}$ is the cross section identifier, $\mathrm{t}$ is the time identifier and $\varepsilon$ represents error term.

\section{Results and Findings}

This section presents the results and finding of the research. The research attempts to explain the determinants of capital structure of internationalized firms in manufacturing sector that are listed in Bursa Malaysia over the 2007-2011 period. This study employed cross sectional panel data. We used pooled ordinary least squares (OLS) regression to estimate the coefficient of the independent variables and the Fixed Effect Model approach to examine the effect of independent variables on debt ratio on the basis of cross sectional variation. The 


\section{MlMacrothink}

Asian Journal of Finance \& Accounting

ISSN 1946-052X

2013, Vol. 5, No. 2

results of the relationship between debt ratios with the independent variables namely internationalization, firm size, profitability, company growth and tangibility are as follows.

Table 1.1 Summary of descriptive statistics

\begin{tabular}{|l|l|l|l|l|l|l|}
\hline & DRATIO & GROWTH & INTL & PROFIT & SIZE & TANG \\
\hline Mean & 0.228 & 1.087 & 0.254 & 0.0472 & 12.23 & 0.354 \\
\hline Median & 0.202 & 0.78 & 0.134 & 0.058 & 12.099 & 0.344 \\
\hline Std. dev. & 0.185 & 1.358 & 0.298 & 0.134 & 1.270 & 0.180 \\
\hline Skewness & 1.710 & 7.527 & 0.995 & -5.463 & 0.626 & 0.290 \\
\hline Kurtosis & 13.69 & 88.57 & 2.815 & 79.24 & 3.829 & 2.825 \\
\hline
\end{tabular}

Table 1.1 demonstrates the descriptive findings for both dependent and independent variables. It can be seen that on average the manufacturing firms in Malaysia have 22.8 percent of debt in their capital structure. This indicates that Malaysian manufacturing firms employ very low level of debt in their capital structure. Besides, tangible or fixed assets account 35.4 percent on average in the firms' total assets. In term of internationalization, on average the manufacturing firms in Malaysia establish stable international diversification by achieving 25.4 percent of foreign sale over their total sale. This confirms that Malaysia is an export-based nation and manufacturing firms contributed most major role in Malaysia's export.

Table 1.2 Correlation Matrix

\begin{tabular}{|l|l|l|l|l|l|l|}
\hline & DRATIO & GROWTH & INTL & PROFIT & SIZE & TANG \\
\hline DRATIO & 1 & & & & & \\
\hline GROWTH & -0.10365 & 1 & & & & \\
\hline INTL & -0.06997 & -0.00203 & 1 & & & \\
\hline PROFIT & -0.16267 & 0.22334 & -0.06191 & 1 & & \\
\hline SIZE & 0.146603 & 0.153085 & -0.05992 & 0.294231 & 1 & \\
\hline TANG & 0.22406 & -0.06053 & -0.04501 & -0.04459 & 0.02162 & 1 \\
\hline
\end{tabular}

Table 1.2 presents the correlation matrix for the sample companies. It shows that company growth and profitability have negative correlation with debt ratio. The negative correlation between debt ratio and profitability affirms the pecking-order theory that firms tend to internalize retained earnings first for further investment and debt financing would serve as second option. Company growth has negative correlation with tangible assets and debt ratio. This implies that when the firms' growth increases, they do not favor in investing in tangible assets but tend to invest in riskier intangible projects. This increases the cost of borrowing and default risk for the debtors, thus results in lower level of debt ratio. The most striking finding in this correlation matrix is that internationalization has negative correlation with the major firm characteristics namely company growth, profitability, firm size, tangibility and debt ratio. Although Malaysia is an export-based country but the recent financial crisis has damaged the manufacturing sector harshly. Firms that have foreign operation or business suffer shrink in term of profitability, growth and firm size from this financial crisis. From 


\section{Mll Macrothink}

Asian Journal of Finance \& Accounting

ISSN 1946-052X

2013, Vol. 5, No. 2

another perspective, this also indicates that Malaysian manufacturing firms encounter huge competitiveness from other rivalry countries in the global platform. The competition is predicted to be more aggressive when the FTAs are implemented fully in future.

Table 1.3 multiple regression results

\begin{tabular}{|c|c|c|c|c|c|c|}
\hline & \multicolumn{3}{|c|}{ Pooled regression } & \multicolumn{3}{|c|}{ Fixed effect regression } \\
\hline Variables & Coefficient & t- statistic & Prob & Coefficient & t- statistic & Prob \\
\hline INTL & -0.013 & -3.28 & 0.00 & -0.025 & -2.42 & 0.01 \\
\hline GROWTH & -0.011 & -3.21 & 0.00 & -0.012 & -2.29 & 0.02 \\
\hline PROFIT & -0.273 & -4.05 & 0.00 & -0.086 & -2.91 & 0.00 \\
\hline SIZE & 0.031 & 26.02 & 0.00 & 0.031 & 2.28 & 0.02 \\
\hline TANG & 0.209 & 11.42 & 0.00 & 0.137 & 2.54 & 0.01 \\
\hline $\mathrm{C}$ & -0.195 & -8.61 & 0.00 & -0.167 & -0.93 & 0.35 \\
\hline $\mathrm{R}^{2}$ & \multicolumn{3}{|l|}{0.12} & \multicolumn{3}{|l|}{0.79} \\
\hline $\begin{array}{l}\text { Hausman } \\
\text { Test }(\chi 2)\end{array}$ & & & & \multicolumn{3}{|l|}{$20.57^{*}$} \\
\hline Adj $R^{2}$ & \multicolumn{3}{|l|}{0.12} & \multicolumn{3}{|l|}{0.75} \\
\hline F-statistic & \multicolumn{3}{|l|}{39.95} & \multicolumn{3}{|l|}{$14.80 *$} \\
\hline
\end{tabular}

* Significant at $1 \%$. White cross-section standard errors \& covariance was used

Table 1.3 summarizes the comparison of multiple regression results between Pooled OLS Model and Fixed Effects Model. Both models confirm and support all the research hypotheses significantly at 0.05 level. However, the R-Squared value $\left(\mathrm{R}^{2}=0.79\right)$ under Fixed Effects Model is much higher than the value of $\mathrm{R}$-Squared $\left(\mathrm{R}^{2}=0.12\right)$ under pooled OLS. The Hausman test with its associated probability $(\mathrm{P}=0.001)$ also reveals that the results under Fixed Effects Model have better explanatory power compared to results under pooled OLS.

\section{Discussion and conclusion}

Internationalization

Empirical results show that research hypothesis 1 is supported, thus, internationalization is negatively related to the debt ratio. The findings are consistent with the studies done by Burgman (1996), Low and Chen (2004), Aggarwal and Kyaw (2010) and Lin and Hung (2012). Burgman (1996) and Low and Chen (2004) investigated and revealed that the negative relationship between internationalization and debt ratio is mainly attributed to US firms. According to "upstream-downstream" hypothesis (Kwok and Reeb, 2000), firms from developed countries increase their risk when they go abroad (downstream- they go to riskier markets) and this leads to a lower debt capacity. Meanwhile, the leverage of firms from emerging markets increases when they could spread the risk by going international (upstream- they go to safer markets). However, the "upstream-downstream" hypothesis cannot fit well in Malaysia situation since Malaysia is an emerging country. The negative relationship in this study can be explained through Pecking-order theory. Firms from emerging countries can achieve economies of scale, access to new market and spread the 
business risk when they pursue strategy of international diversification. Given these advantages, internationalized firms have greatly increased their foreign sales and profitability. As Pecking-order theory predicts, profitable firms would first internalize the retained earnings for future investment rather than borrowing debt. Thus, leverage of these firms would decrease. It is supported by the studies by Aggarwal and Kyaw (2010) and Lin and Hung (2012) as their research results indicated that internationalized firms generate greater profitability and have lower debt ratio compared to domestic firms. The inverse relationship between internationalization and debt ratio is also consistent with the implications of agency theory. Malaysia is an export-based country. Most of the listed manufacturing firms enter foreign markets through exporting goods abroad. Agency cost of debt increases when creditors often find themselves difficult to monitor the selling activities oversea due to the complexity of foreign operation. Therefore, creditors become less willing to lend funds to the exporting firms. Chen and $\mathrm{Yu}$ (2011) presented findings that are consistent with this agency theory when their investigation showed that exporting firms have lower debt ratio meanwhile firms with FDI abroad have higher leverage.

\section{Firm Size}

The empirical findings supported research hypothesis 2 , thus, firm size is positively related to the debt ratio. The findings are consistent with the studies of Krishnan and Moyer (1997), Titman and Wessels (1998), Hall et al (2000), Suto (2003) and Sheikh and Wang (2011). The result confirms the static trade-off theory that postulates larger firms should operate at higher leverage level in order to take the benefits of tax shield on debt interest payment. Besides, a large and multi product company is more stable therefore the business risk is low compare to a small and single product company. As a result, the possibility to bankrupt for larger companies are low and they can sustain a higher level of debt. Incidentally, large companies will be able to enjoy economies of scales in issuing long-term debt, and have a strong negotiating power with lenders. Thus, larger firms tend to have higher debt ratio.

\section{Profitability}

The empirical results supported the research hypothesis 3, thus, profitability is negatively related to the debt ratio. The findings are in line with studies by Ross (1977), Rajan and Zingales (1998), Suto (2003), Panno (2003), Chen (2004), Chakraborty (2010), Chen and Yu (2011) and Sheikh and Wang (2011). The results are as expected by the Pecking-order theory. According to pecking-order theory, managers will prefer internally generated funds to external financing when they cannot credibly convey inside information to outsiders. First, managers will choose internal finance. Secondly, managers will choose to borrow when their investment cannot be met by internal finance. The managers will only issue the equity as the least preferred choice when the options of borrowing were exhausted. Furthermore, as mentioned earlier, debt financing is obligated to a fixed interest payment regardless of the company's performance. Thus, in the short run, profitability is negatively correlated with leverage.

\section{Company Growth}

The empirical results supported the research hypothesis 4, thus, company growth is negatively related to the debt ratio. The findings are consistent with studies of Titman and 
Wessels (1998) and Eldomiaty (2008). The inverse relationship between company growth and debt ratio is in line with assumptions of agency theory. Most often, higher growth opportunities provide incentives to invest. The high investment increases the cost of borrowing and lead to smaller pool of debt funds. Thus, growth firms tend to use internalized funds or equity rather than debt. Moreover, firms experiencing high growth rates prefer not to increase its level of debt because their cash flow might not sustain servicing the debt when needed.

\section{Tangibility}

The empirical results supported the research hypothesis 5, thus, tangibility is positively related to the debt ratio. The findings are in line with many previous studies such as Rajan and Zingales (1995), Bevean and Danbolt (2001), Suto (2003), Pandey (2007) and Chakraborty (2010). The positive relationship between tangibility and debt ratio can be explained by the static trade-off theory and Pecking-order theory. From a static trade-off perspective, firms with a lot of fixed assets find it easier to issue bonds or get loan from banks because the fixed assets of the company will be able to serve as collateral for the borrowing and reduces the default risk for the lenders. Under the Pecking-order theory, the greater the value of the tangible assets, the smaller the asymmetric information, therefore, it is expected that the collateral value might be positively related to the debt ratio.

\section{Conclusion and Implications}

The empirical evidence from this study showed that internationalized manufacturing firms have lower debt ratio than the domestic manufacturing firms. This documented important implications to the internationalized firm managers, policy makers, investors and academic researchers who are interested in international finance. For example, the internationalized firm managers and policy makers should encourage the company to engage on international diversification. According to Pecking-order theory, companies that pursue international diversification can spread the business risk from one solely market to other regional markets. Besides, the results of this study showed that internationalized firms are likely to have lower leverage. Thus, the firms are considered less risky as the firms do not much obligation in paying the debt interest payment. This is even risk-reducing as the firms are less borne to the bankruptcy costs when facing financial crisis. In the view of equity investors, the stock of internationalized firms is preferred than the stock of domestic firms. As explained above, internationalized firms have lower debt; the reduced bankruptcy costs and less debt interest payment obligation make the firms less risky and more financially stable. Vice versa, the debt investors should invest by lending the fund in the domestic firms. The agency problem such as monitoring costs can be mitigated as the debt investors can assess these domestic firms without extra monitoring costs compared to internationalized firms. Therefore, this study portrayed the consistent results that domestic firms have higher debt ratio. Future research may extend this study in more details by adopting more independent variables. It is suggested to include other definitions of capital structure such as short-term debt ratio and long-term debt ratio. The decomposition of capital structure can give clearer insights in the relationships of the determinants with the capital structure. Besides, financial data should 
cover longer period such as 10 -years period in order to give more consistent insight for the complete business cycle.

\section{References}

Aggarwal, R. and Kyaw, N. A. (2010). Capital structure, dividend policy, and multinationality: Theory versus empirical evidence. International Review of Financial Analysis 19(2), 140-150. http://dx.doi.org/10.1016/j.irfa.2010.01.001

Booth, A. A., Aivazian, V., Demirguc-Kunt, A., \& Maksimovic, V. (2001). Capital Structure in Developing Countries. Journal of Finance, 56 (1), 87-130. http://dx.doi.org/10.1111/0022-1082.00320

Braitsford, T., Oliver, B., \& Pua, S. (2002). On the Relation between Ownership Structure and Capital Structure. Accounting and Finance, 42, 1-26. http://dx.doi.org/10.1111/1467-629X.00001

Burgman, T. A. (1996). An Empirical Examination Of multinational Corporate Capital Structure. Journal of International Business Studies, 27(3), 553-570. http://dx.doi.org/10.1057/palgrave.jibs. 8490143

Cassar, G., \& S. Holmes, (2003). Capital structure and financing of SMEs: Australian $\begin{array}{llll}\text { evidence. Accounting } \quad \& \quad \text { Finance, } & \text { 43(2), }\end{array}$ http://dx.doi.org/10.1111/1467-629X.t01-1-00085

Chakraborty, I. (2010). Capital structure in an emerging stock market: The case of India. Research in International Business and Finance 24(3), 295-314. http://dx.doi.org/10.1016/j.ribaf.2010.02.001

Chen, C. J. P., Cheng, C. S. A., He, J., \& Kim, J. (1997). An Investigation of the Relationship between International Activities and Capital Structure. Journal of International Business Studies, 28(3), 563-577. http://dx.doi.org/10.1057/palgrave.jibs.8490111

Chen, C. J., \& Yu, C. M. (2011). FDI, Export, and Capital Structure. An Agency Theory Perspective. Management International Review, 51(3), 295-320. http://dx.doi.org/10.1007/s11575-011-0077-0

Chen, J. J. (2004). Determinants of capital structure of Chinese-listed companies. Journal of Business Research, 57(12), 1341- 1351. http://dx.doi.org/10.1016/S0148-2963(03)00070-5

Chkir, I. E., \& J. Cosset, (2001). Diversification Strategy and Capital Structure of Multinational Corporations. Journal of Multinational Financial Management, 11(1), 17-37. http://dx.doi.org/10.1016/S1042-444X(00)00040-2

Eldomiaty, T. I. (2008). Determinants of corporate capital structure: evidence from an emerging economy. International Journal of Commerce and Management, 17(1), 25 - 43.

Hall, G., Hutchinson, P., \& Nicos, M. (2000). Industry Effect on the Determinants of Unquoted SME's Capital Structure. International Journal of Economic Business, 7(3), 297-312. http://dx.doi.org/10.1080/13571510050197203 
Harris, M., \& Raviv, A. (1991). The Theory of Capital Structure. Journal of Finance, 46(1), 297-355. http://dx.doi.org/10.1111/j.1540-6261.1991.tb03753.x

Hitt M. A., Hoskisson R. E., \& Kim H. (1997). International Diversification: Effects on innovation and firm performance in product-diversified firms. The Academy of Management Journal, 40(4), 767-98. http://dx.doi.org/10.2307/256948

Hitt, M. A., Hoskisson, R. E., \& Ireland, R. D. (1994). A Mid-range Theory of the Effects of International and Product Diversification on Innovation and Performance. Journal of Management 20(2), 297-326. http://dx.doi.org/10.1016/0149-2063(94)90018-3

Hull, E. H., \& Lee, J. (1999). Broadening the View of Corporate Diversification: An International Perspective. The International Journal of Organizational Analysis, 7(1), 25-53.

Kester, G., \& Mansor, M. (1994). Capital Structure Policy in Malaysia: A Comparative Analysis. Asian Journal of Business and Accounting, 1(2), 175-192.

Kobrin S. J. (1991). An empirical analysis of the determinants of global integration. Strategic Management Journal, 10 (1), 17-31.http://dx.doi.org/10.1002/smj.4250120904

Krishnan, V. S., \& Moyer, R. C. (1997). Performance, Capital Structure and Home Country: An Analysis of Asian Corporations. Global Finance Journal, 8(1), 129-143 http://dx.doi.org/10.1016/S1044-0283(97)90010-7

Kwok, C. C. Y., \& Ramirez, A. (2010). Settling the debate on multinational capital structure using the CEPR measure. Journal of Multinational Financial Management, 20(4-5), 251-271. http://dx.doi.org/10.1016/j.mulfin.2010.07.004

Kwok, C. C. Y., \& Reeb, D. M. (2000). Internationalization and Firm Risk: An Upstream-downstream Hypothesis. Journal of International Business Studies, 31(4), 611-629. http://dx.doi.org/10.1057/palgrave.jibs.8490925

Lin, F. L., \& Hung, J. Y. (2012). Internationalization and Capital Structure of Taiwan Electronic Corporation. International Business Research, 5(1), 164-171.

Low, P. Y., \& Chen, K. H. (2004). Diversification and Capital Structure: Some International Evidence. Review of Quantitative Finance and Accounting, 23(1), 55-71. http://dx.doi.org/10.1023/B:REQU.0000037064.15144.04

Malaysia External Trade Development Corporation. http://www.matrade.gov.my/en/malaysia-exporters-section/123-trade-performance-2009/129trade-performance-january-2009

Mohd, M., Perry, L., \& Rimbey, J. (1998). The Impact of Ownership Structure on Corporate Debt Policy: A Time-series Cross-sectional Analysis. The Financial Review, 33(3), 85-98. http://dx.doi.org/10.1111/j.1540-6288.1998.tb01384.x

Myers, C. (1984). The Capital Structure Puzzle. The Journal of Finance 39(3), 575-592.

Ooi, J. (1999). The Determinants of Capital Structure - Evidence on UK Property Companies. 
Journal of Property Investment \& Finance, 17(5), 464-480. http://dx.doi.org/10.1108/14635789910294886

Pandey I.M. (2007). Capital Structure, Profitability and Market Structure: Evidence Malaysia. Asia Pacific journal of Economics\& Business, 8(2), 78-91

Panno, A. (2003). An Empirical Investigation on the Determinants of Capital Structure. Applied Financial Economics, 13(2), 97-112. http://dx.doi.org/10.1080/09603100210100882

Petersen, M.A., \& Rajan, R.G. (1994). The Benefits of Lending Relationships: Evidence from Small Business Data. Journal of Finance, 49(1), 3-37. http://dx.doi.org/10.1111/j.1540-6261.1994.tb04418.x

Rajan, R. G., \& L. Zingales, (1995). What do We Know about Capital Structure? Some Evidence from International Data. Journal of Finance, 50(5), 1421-1460. http://dx.doi.org/10.1111/j.1540-6261.1995.tb05184.x

Ross, S. (1977). The Determination of Capital Structure: The Incentive Signaling Approach. Bell Journal of Economics, 8(1), 23-40. http://dx.doi.org/10.2307/3003485

Schmukler, S., \& Vesperoni, E. (2000). Globalization and Firms' Financing Choices: Evidence from Emerging economies. Policy Research Working paper, No. WPS 2323, The World Bank.

Shapiro, A. C., (1992). Multinational Financial Management (4th ed). Boston: Allyn and Bacon.

Sheikh, N. A. and Wang, Z. J. (2011). Determinants of capital structure: An empirical study of firms in manufacturing industry of Pakistan. Managerial Finance, 37(2), 117 - 133. http://dx.doi.org/10.1108/03074351111103668

Singh, M., Davidson, W. N., \& Suchard, J.A. (2003). Corporate diversification strategies and capital structure. The Quarterly Review of Economics and Finance, 43(1), 147-167. http://dx.doi.org/10.1016/S1062-9769(02)00124-2

Suto, M. (2003). Capital Structure and Investment Behavior of Malaysian Firms in the 1990s: A Study of Corporate Governance Before The Crisis. International Corporate Governance Review, 11(1), 25-39. http://dx.doi.org/10.1111/1467-8683.00299

Thomas, D. E., \& Eden L. (2004). What Is the Shape of the Multi-nationality Performance Relationship? Multinational Business Review, 12(1), 89 - 110.

Thomas, D. E. (2006). International diversification and firm performance in Mexican firms: A curvilinear relationship? Journal of Business Research, 59(4), 501-507 http://dx.doi.org/10.1016/j.jbusres.2005.08.008

Titman, S., \& Wessels, R. (1998). The Determinants of Capital Choices. Journal of Finance, 43(1), 1-19. http://dx.doi.org/10.1111/j.1540-6261.1988.tb02585.x

Warner, J. (1997). Bankruptcy Cost: Some Evidence. Journal of Finance, 32(2), 337-347. http://dx.doi.org/10.2307/2326766 